\title{
Large scale ex vivo expansion of clinical-grade effector cells for adoptive immunotherapy
}

\author{
HUIYING YU, WEI CHEN, CHANGLING LI, DI LIN, JUNDE LIU, ZIEN YANG, \\ JINGANG YANG, YINGHUI SUN and DONGCHU MA
}

Department of Experimental Medicine, Northern Hospital, Shenyang, Liaoning 110016, P.R. China

Received February 4, 2017; Accepted August 4, 2017

DOI 10.3892/etm.2017.5228

\begin{abstract}
Cell-based adoptive immunotherapy for the treatment of various cancer types has attracted the attention of scientists. However, due to the absence of unitary standard protocols to produce large quantities of clinical-grade effector cells, it remains challenging to translate the experimental findings into clinical applications. The present study used methods complying with good manufacturing practice to induce effector cells from human peripheral blood mononuclear cells (PBMCs) of healthy donors by interleukin-2 and anti-Her-2 antibody with or without anti-CD3 antibodies (OKT3). The results indicated that the addition of OKT3 resulted in a greater expansion of the total cells and $\mathrm{CD}^{+} \mathrm{T}$ cells, and primarily induced the PBMCs to differentiate into $\mathrm{CD}^{+} \mathrm{T}$ cells. Regardless of the presence of OKT3, the expression of activating receptor of natural killer (NK) group 2, member $\mathrm{D}$, and the inhibitory receptors of CD158a and CD158b on NK cells and NKT cells was increased, while the expression of NKp46 was inhibited on NK cells, but not on NKT cells. Furthermore, OKT3 did not affect the toxicity of the effector cells. Subgroup analysis indicated that although a variation of the composition of effector cells was present in different individuals under identical culture conditions, consistent marker expression on effector cells and target cell-killing effects were observed in different subgroups treated with or
\end{abstract}

Correspondence to: Professor Dongchu Ma, Department of Experimental Medicine, Northern Hospital, 83 Wenhua Road, Shenyang, Liaoning 110016, P.R. China

E-mail: mdc580819@sina.com

Abbreviations: GMP, good manufacturing practice; PBMC, peripheral blood mononuclear cells; IL, interleukin; NK, natural killer; CIK, cytokine-induced killer; CAR-T, chimeric antigen receptor-engineered T cells; MHC, major histocompatibility complex; HLA-I, human leukocyte antigen class I; ADCC, antibody-dependent cell-mediated cytotoxicity; TTZ, trastuzumab; LDH, lactate dehydrogenase; NKPG, NK cell-predominant phenotyping group; $\mathrm{CD} 8 \mathrm{PG}, \mathrm{CD}^{+}$cell-predominant phenotyping group; NK + CD8BG, $\mathrm{NK}$ and $\mathrm{CD} 8^{+} \mathrm{T}$ cell-balanced phenotyping group

Key words: adoptive immunotherapy, effector cells, Her-2 without OKT3. Furthermore, western blot analysis indicated that OKT3, apart from its involvement in cell cycle regulation, affects transcription and protein translation during processes of proliferation and differentiation. The present study provided experimental data regarding the production of effector cells for adoptive immunotherapy as a clinical application.

\section{Introduction}

Adoptive immunotherapy is considered a promising treatment for cancer patients (1). Patients' own immune cells are collected and induced ex vivo to proliferate and differentiate into effector cells with increased quantity and antitumor effects, and then re-administrated to the patients via infusion. Effector cells prepared ex vivo for infusion include non-specifically activated lymphocytes, including natural killer (NK) cells (2), cytokine-induced killer (CIK) cells (3), NKT cells, tumor antigen-specific $\mathrm{T}$ cells, including chimeric antigen receptor-engineered T cells (CAR-T) (4) and T cell receptor engineered $\mathrm{T}$ cells (5). Although a recent study has demonstrated the efficacy of CAR-T therapy in treating hematologic malignancies, their effects on solid tumors are far less known (6).

Adoptive non-specific immune effector cell infusion has an important role in the treatment of a variety of solid tumor types. NK cells $\left(\mathrm{CD}^{-}{ }^{-} \mathrm{CD} 56^{+}\right)$are effectors of innate immunity in peripheral blood, spleen, bone marrow, intestine, liver and uterus (7). They migrate to lymph nodes and secondary lymphoid organs to build the first line of defense against invading pathogens as well as to provide antitumor immune responses (8). Receptors on the NK cell surface interact with ligands on tumor cells without restriction by the major histocompatibility complex (MHC). NK cells recognize and kill tumor cells, targeting them based on a reduced or absent expression of human leukocyte antigen class I molecules (9).

CIK cells are generated ex vivo from peripheral blood mononuclear cells (PBMCs) using anti-CD3 antibodies (OKT3) and various cytokines. Expanded CIK cells are a heterogeneous lymphocyte population of $\mathrm{CD}^{+} \mathrm{CD} 56^{+}$ NKT cells, $\mathrm{CD}^{+}{ }^{+} \mathrm{CD} 56^{-} \mathrm{T}$ lymphocytes, and a minority of CD3 ${ }^{-}$D5 $6^{+}$NK cells (10). Under CIK culture conditions, expanded $\mathrm{CD}^{+}{ }^{+} \mathrm{CD} 56^{+}$cells are derived from $\mathrm{CD} 3{ }^{+} \mathrm{CD} 56$ $\mathrm{T}$ cells rather than $\mathrm{CD} 3{ }^{-} \mathrm{CD} 56^{+} \mathrm{NK}$ cells. The majority of the $\mathrm{CD}^{+}{ }^{+} \mathrm{CD} 56^{+}$cells co-express $\mathrm{CD} 8$ but not $\mathrm{CD} 4$, which is 
consistent with the high level of effector $\mathrm{CD}^{+} \mathrm{T}$ cell cytotoxic activity (11). CIK cells differ from NK cells in that they do not mediate antibody-dependent cell-mediated cytotoxicity (ADCC). Alternating infusions of CIK and NK cells provide an enhanced synergistic antitumor immunity compared to adoptive immunotherapy with CIK cells alone (12). Innate immune cells function to support adaptive immune responses by enhanced direct tumor cell cytolysis and optimal antitumor T-cell activity (13).

Within the current regulatory paradigm, clinical translation of adoptive immunotherapy requires good manufacturing practice (GMP)-compliant processes to produce clinically relevant quantities of antitumor immune effectors. In this respect, clinical-grade CIK cells may be expanded ex vivo under relatively simple and low-cost GMP-compliant culture conditions, which offer important advantages over other cell therapy products, including NK cells, tumor-infiltrating lymphocytes and CAR-T. The major challenge with NK cell immunotherapy has been to obtain large quantities of NK cells with high purity. At present, the source of precursor cells, the collection methods, quality control and evaluation of treatment outcomes vary among laboratories (14). Certain protocols rely on the use of feeder cells to promote the proliferation of NK cells (15-18). However, these methods may be restricted by GMP guidelines, which hinder the clinical application of NK cells in immunotherapy (19).

Trastuzumab (TTZ, Herceptin ${ }^{\circledR}$ ) is a human anti-HER-2 monoclonal antibody used for treating breast cancer, metastatic gastric adenocarcinoma and adenocarcinoma of the gastroesophageal junction (20). TTZ bears two antigen-specific sites that bind to the extracellular domain of the HER2 receptor and that prevent the activation of its intracellular tyrosine kinase (21). The remainder of the antibody is human immunoglobulin $(\mathrm{Ig}) \mathrm{G}$ with a conserved fragment crystallizable $(\mathrm{Fc})$ portion. Preclinical studies using models suggested the contribution of ADCC to the therapeutic benefit of TTZ. ADCC occurs when antibodies bind to antigens on tumor cells and the Fc domains of the antibody recruit $\mathrm{Fc}$ receptor-bearing effector cells, including NK cells and macrophages (22). Manipulations of the Fc domain structure may optimize antibody clearance and the interaction of Fc domains with cellular Fc receptors (23). Furthermore, immobilization of TTZ increased the number of PBMCs from 5 healthy donors after $48 \mathrm{~h}$ of culture, which indicated that this technique is effective for culturing cells for immunotherapy (24).

The present study investigated the proliferation of PBMCs derived from 22 healthy donors, their expression of activating and inhibitory receptors and the cytotoxicity in effector cell culture using large-scale ex vivo GMP-compliant culture systems based on anti-HER-2 antibody in order to optimize the culture conditions for clinical-grade effector cells.

\section{Materials and methods}

Study design. Following the attainment of informed consent, fresh heparinized peripheral blood samples were collected from 22 healthy donors (13 males and 9 females; median age, 34.5 years; age range, 22-68 years). PBMCs were isolated by density gradient centrifugation in lymphocyte separation medium (GE Healthcare, Little Chalfont, UK) according to the manufacturer's protocol. The PBMCs from all 22 healthy donors were cultured in one of the expansion systems listed below. Cell proliferation, phenotype, expression of NK cell receptors and cytotoxicity against target cells were compared between the two systems.

Effector cell expansion system. In brief, PBMCs were cultured in effector cell expansion systems (system A or system B). Cells were suspended in $20 \mathrm{ml}$ ALyS505NK-AC culture media (Center for Stem Cell Therapeutics and Imaging, Inc., Sendai, Japan) containing 1,000 IU/ml interleukin 2 (IL-2; Sansheng, Jiangyin, China) and 1\% autologous heat-inactivated plasma. All cells were then inoculated into $75-\mathrm{cm}^{2}$ culture flasks coated with $0.48 \mathrm{mg} / \mathrm{ml}$ anti-HER2 monoclonal antibody (GTIN: 07640149610680; Genentech Inc., Roche, San Francisco, CA, USA) at a concentration of $2 \times 10^{6}$ cells $/ \mathrm{ml}$ and incubated for 5 days. The modification of system $\mathrm{B}$ was the addition of anti-CD3 antibody (cat. no. 170-076-116; Miltenyi Biotec, Bergisch Gladbach, Germany) to the media at a concentration of $50 \mathrm{ng} / \mathrm{ml}$ on day 1 . In the two systems, cells and media were transferred to a gas-permeable cell culture bag (Nipro Corp., Osaka, Japan) with $200 \mathrm{ml}$ ALyS505NK-EX culture media containing $1,000 \mathrm{IU} / \mathrm{ml} \mathrm{IL}-2$ on day 5 and cultured for another 8 days. The media were changed every 2-3 days.

Flow cytometry. Aliquots of cells were incubated for $15 \mathrm{~min}$ at room temperature $\left(20-25^{\circ} \mathrm{C}\right)$ in the dark with fluorochrome-conjugated $\mathrm{mAb}$ for phenotypic analysis. CD4 fluorescein isothiocyanate (FITC)/CD8 phycoerythrin (PE)/CD3 peridinin chlorophyll (PerCp) (cat. no. 340298; 1:5), CD56allophycocyanin(APC) (cat.no.341025; 1:20), CD3 FITC (cat. no. 555339; 1:5), CD8 PerCP-Cy ${ }^{\mathrm{TM}} 5.5$ (cat. no. 560662; 1:20), CD94/NKG2C PE (cat. no. 555889; 1:5), CD158a PE (cat. no. 556063; 1:5), CD158b PE (cat. no. 559785; 1:5) and CD335/NKP46 PE (cat. no. 557991; 1:5) were obtained from BD Biosciences (San Jose, CA, USA), and CD314/NK group 2, member D (NKG2D) APC (cat. no. FAB139P; 1:10) from R\&D Systems (Minneapolis, MN, USA). Isotypes of the equivalent antibodies were used as negative controls and incubated for $15 \mathrm{~min}$ at room temperature in the dark. FastImmune $\mathrm{e}^{\mathrm{TM}}$ Control $\gamma 1 / \gamma 1 /$ CD3 (cat. no. 340369; 1:5), PE Mouse IgM, $\kappa$ Isotype Control (cat. no. 555584; 1:5), PerCP-Cy ${ }^{\mathrm{TM}} 5.5$ Mouse IgG1, $\kappa$ Isotype Control (cat. no. 550795; 1:5), PE Mouse IgG1, $\kappa$ Isotype Control (cat. no. 555749; 1:5), FITC Mouse IgG2a, $\kappa$ Isotype Control (cat. no. 555573; 1:5), PE Mouse IgG2b, $\kappa$ Isotype Control (cat. no. 555743; 1:5), APC Mouse IgG2b, к Isotype Control (cat. no. 555745; 1:5) were obtained from BD Biosciences with the exception of mouse IgG1 PE-conjugated antibody (cat. no. IC002P; 1:10; R\&D Systems). Samples were measured with a flow cytometer (FACSCanto II; BD Biosciences). Analysis of flow cytometric data was performed using of BD FACSDiva software version 6.1.2 (BD Biosciences).

Cytotoxicity assay. Cytotoxicity was determined using a CytoTox $96^{\circledR}$ Non-Radioactive Cytotoxicity Assay (Promega Corp., Madison, WI, USA) based on the exocytic release of lactate dehydrogenase (LDH), according to the manufacturer's 
protocol. On day 14, the cells were harvested, washed, counted and added to target cells (K562 cells, ATCC ${ }^{\circledR}$ CCL-243 ${ }^{\mathrm{TM}}$; American Type Culture Collection, Manassas, VA, USA) at a ratio of 20:1 or 10:1 in 96-well, round-bottomed plates (Falcon; Thermo Fisher Scientific, Inc., Waltham, MA, USA) in triplicates and incubated for $4 \mathrm{~h}$ at $37^{\circ} \mathrm{C}$ in a humidified atmosphere containing $5 \% \mathrm{CO}_{2}$. Plates were then centrifuged for $3 \mathrm{~min}$ at $200 \mathrm{x} \mathrm{g}$ and the supernatant from each well was transferred to a 96-well flat-bottomed plate. The LDH levels in the supernatant were quantified according to the absorbance at 492 nm (Thermo Multiskan MK3; Thermo Fisher Scientific, Inc.). The percentage of $\mathrm{LDH}$ released reflected the antitumor activities of the effector cells. The cytotoxicity percentage was calculated as follows: Cytotoxicity $(\%)=[($ experimental release-spontaneous release of effector cells-spontaneous release of target cells)/(maximal release of target cells-spontaneous release of target cells)] x100\%.

Re-stimulation of $\mathrm{CD}^{+} \mathrm{T}$ cells and $\mathrm{NK}$ cells with soluble anti-CD3 and $I L-2$. CD8 ${ }^{+} \mathrm{T}$ cells and NK cells were purified from the cultured cells harvested on day 9 from system B using a human CD8 ${ }^{+}$T cell enrichment kit (cat. no. 19053; Stemcell Technologies, Inc., Vancouver, BC, Canada) and a human NK cell enrichment kit (cat. no. 19055; Stemcell Technologies, Inc.), respectively. Purified $\mathrm{CD}^{+} \mathrm{T}$ cells and NK cells were either cultured with medium alone or re-stimulated with IL-2 $(1,000 \mathrm{IU} / \mathrm{ml})$, or with anti-CD3 $(50 \mathrm{ng} / \mathrm{ml})$ and IL-2 $(1,000 \mathrm{IU} / \mathrm{ml})$ for $24 \mathrm{~h}$ prior to being harvested for western blot analysis.

Western blot analysis. Cells were harvested and washed twice with PBS. The cell pellets were lysed with sample buffer (62.5 mM Tris-HCl, 10\% glycerol, 10\% (w/v) SDS, $1 \mathrm{mM}$ phenylmethylsulfonyl fluoride and $50 \mathrm{mM}$ dithiothreitol) and sonicated for $6 \mathrm{~min}$ on ice to shear DNA and reduce sample viscosity. Cell lysates were cleared by centrifugation at $9600 \mathrm{x} \mathrm{g}$ for $5 \mathrm{~min}$ at $4^{\circ} \mathrm{C}$. The protein concentration was measured by means of a bicinchoninic acid protein assay reagent kit (Pierce; Thermo Fisher Scientific, Inc.) to ensure equal loading. Lysates (30 $\mu \mathrm{g} /$ lane) were subjected to $6-12 \%$ SDS-PAGE gel and transferred to a nitrocellulose membrane. Blots were blocked with $5 \%$ non-fat milk in Tris-buffered saline containing $0.1 \%$ Tween-20 (TBST) for $2 \mathrm{~h}$ at room temperature. The membranes were incubated overnight at $4^{\circ} \mathrm{C}$ with different primary antibodies. Akt (cat. no. 4691; 1:1,000), p-Akt (Ser473; cat. no. 9271; 1:1,000), CDK2 (cat. no. 2546S; 1:1,000), p-CDK2 (Thr160; cat. no. 2561S; 1:1,000), JAK (cat. no. 3344; 1:1,000), PI3K p85 (cat. no. 4257; 1:1,000), p-PI3K [p85 (Tyr458)/p55 (Tyr199); cat. no. 4228; 1:1,000], p-P70S6K (Thr421/Ser424; cat. no. 9204; 1:1,000), S6 (cat. no. 2217; 1:1,000), P-S6 (Ser235/236; cat. no. 2211; 1:1,000), p-S6 (Ser240/244; cat. no. $2215 ; 1: 1,000$ ), STAT3 (cat. no. 4904; 1:1,000), p-STAT3 (Tyr705; cat. no. 9131; 1:1,000), STAT5 (cat. no. 9358; 1:1,000) and p-STAT5 (Tyr694; cat. no. 9351; 1:1,000) were obtained from Cell Signaling Technologies, Inc. (Danvers, MA, USA). Cyclin D3 (cat. no. sc-182; 1:2,00), cyclin B1 (cat. no. sc-752; 1:5,00) and p70S6K $\alpha$ (cat. no. sc-230; 1:5,00) were obtained from Santa Cruz Biotechnology, Inc. (Dallas, TX, USA). p-p70S6K (Thr389; cat. no. MA5-15117, 1:1,000) was

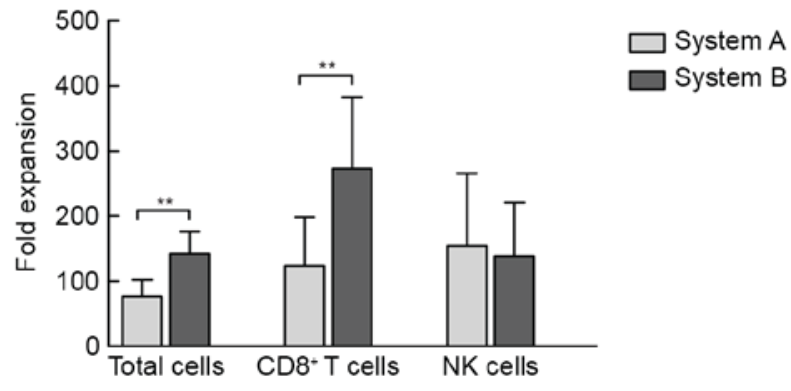

Figure 1. Comparison of cell expansion in the different ex vivo culture systems. Fold expansion of total cells, $\mathrm{CD}^{+} \mathrm{T}$ cells and NK cells was measured via comparing the number of cells harvested on day 14 with the number of cells initially seeded on day 0 in system A (light gray bar) and $\mathrm{B}$ (dark gray bar). Values are expressed as the mean \pm standard error of the mean $(n=22) .{ }^{* *} \mathrm{P}<0.01$, system $\mathrm{B}$ vs. system $\mathrm{A}$, paired-samples t-test. NK, natural killer; System A/B, induction in the absence/presence of anti-CD3.

obtained from Thermo Fisher Scientific Inc. and GAPDH (cat. no. G9545; 1:60,000) was obtained from Sigma-Aldrich; Merck KGaA (Darmstadt, Germany). Following three washes in TBST, the membranes were incubated with horseradish peroxidase-conjugated goat anti-rabbit IgG (heavy and light chains; cat. no. 31460; 1:60,000; Pierce; Thermo Fisher Scientific, Inc.) at room temperature for $2 \mathrm{~h}$. Reactive proteins were detected with LumiGLO ${ }^{\text {TM }}$ reagent (Cell Signaling Technologies, Inc.) and immunoblots were imaged on X-ray film (cat. no. 4741008378; Fujifilm Holdings Corporation, Tokyo, Japan).

Statistical analysis. Values are expressed as the mean \pm standard error of the mean. Differences between groups were assessed for statistical significance by the Mann-Whitney test or paired Student's t-test depending on the distribution of the data. One-way analysis of variance and Tukey-Kramer multiple comparisons post hoc test were applied when comparing more than two groups. SPSS software (version 22; IBM Corp., Armonk, NY, USA) was used for all statistical analyses. $\mathrm{P}<0.05$ was considered to indicate a statistically significant difference.

\section{Results}

Expansion and immunophenotypic characterization of effector cells. At 14 days after induction, the median expansion of the cultured products from 22 healthy donors was 80 -fold (range, 18.5 to 125 -fold) and 147.50-fold (range, 64.0 - to 205-fold) in system A and system B, respectively. The mean expansion fold of total cells as well as $\mathrm{CD} 8^{+} \mathrm{T}$ cells in system B was significantly greater than that in system A $(\mathrm{P}<0.01$; Fig. 1).

Additional phenotypic analysis revealed that the percentages of $\mathrm{CD}^{+} \mathrm{T}$ cells, $\mathrm{CD}^{+} / \mathrm{CD}^{+} \mathrm{T}$ cells and $\mathrm{CD}^{+} / \mathrm{CD}^{+} \mathrm{T}$ cells in the final products of system $\mathrm{B}$ were significantly higher than those of system A. By contrast, the percentages of NK $\left(\mathrm{CD}^{-} / \mathrm{CD}^{2} 6^{+}\right)$and $\mathrm{NKT}\left(\mathrm{CD}^{+} / \mathrm{CD}^{2} 6^{+}\right)$cells in system $\mathrm{B}$ were significantly lower than those expanded in system A (Table I).

Expression of cell surface receptors on NK and NKT cells. In the present study, three-color fluorescence flow cytometry 
Table I. Phenotype analysis (\%) of the final cell products in different culture systems.

\begin{tabular}{lllccc}
\hline System & $\mathrm{CD}^{+}$ & $\mathrm{CD}^{+} \mathrm{CD} 8^{+}$ & $\mathrm{CD}^{+}{ }^{+} \mathrm{CD} 4^{+}$ & $\mathrm{CD}^{+}{ }^{+} \mathrm{CD} 56^{+}$ & $\mathrm{CD}^{+}{ }^{-} D 56^{+}$ \\
\hline A & $66.2 \pm 20.6$ & $46.1 \pm 21.6$ & $9.6 \pm 7.2$ & $25.2 \pm 19.3$ & $31.2 \pm 20.5$ \\
B & $81.9 \pm 13.4^{\mathrm{a}}$ & $52.8 \pm 13.0^{\mathrm{b}}$ & $26.9 \pm 15.3^{\mathrm{a}}$ & $16.5 \pm 11.3^{\mathrm{a}}$ & $16.9 \pm 13.3^{\mathrm{a}}$ \\
\hline
\end{tabular}

${ }^{\mathrm{a}} \mathrm{P}<0.01,{ }^{\mathrm{b}} \mathrm{P}<0.05$ system A vs. system $\mathrm{B}$. Values are expressed as the mean \pm standard error of the mean $(\mathrm{n}=22)$. System $\mathrm{A} / \mathrm{B}$, induction in the absence/presence of anti-CD3.

A

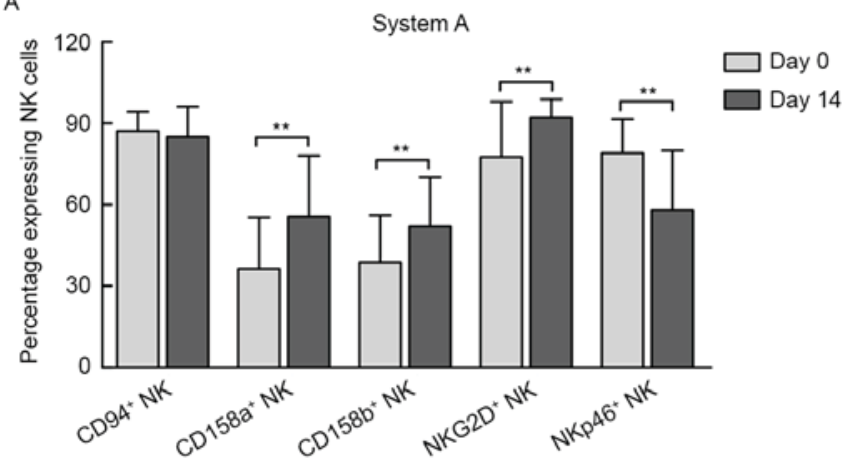

B

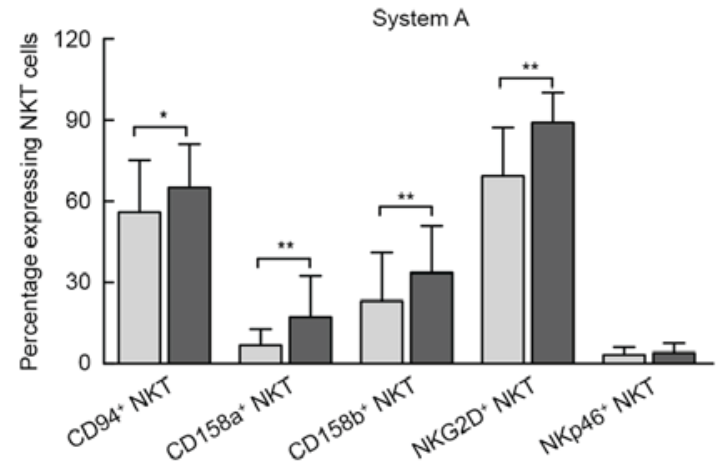

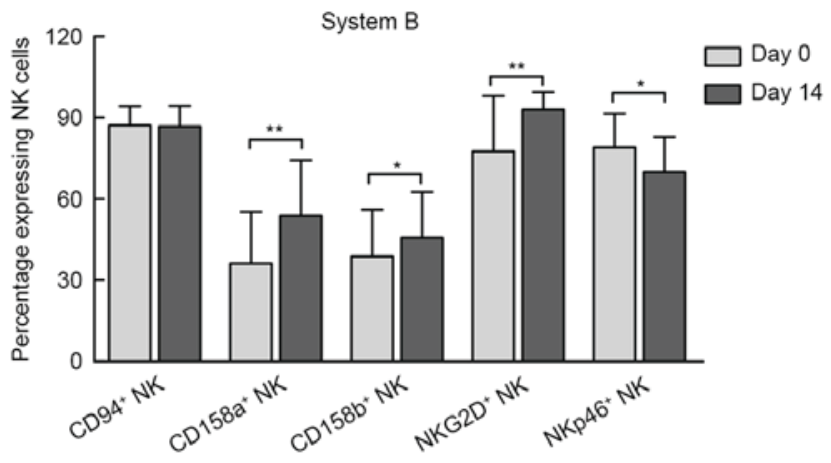

System B

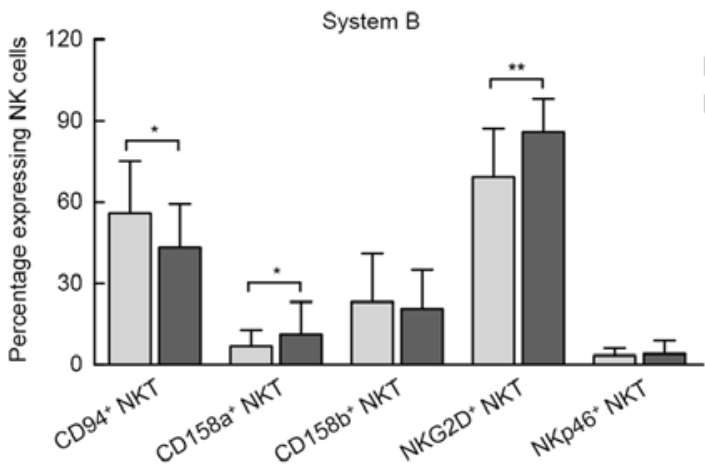

Figure 2. Cell-surface receptor expression on NK and NKT cells in different culture systems. Three-color fluorescence flow cytometry was used to analyze the percentage of associated cell-surface receptor-positive (A) NK and (B) NKT cells in isolated peripheral blood mononuclear cells on day 0 (light gray bar) or expanded cells on day 14 (dark gray bar). Values are expressed as the mean \pm standard error of the mean $(\mathrm{n}=22)$. ${ }^{*} \mathrm{P}<0.05,{ }^{* * *} \mathrm{P}<0.01$ (paired-samples $\mathrm{t}$-test). System A/B, induction in the absence/presence of anti-CD3; NKG2D, natural killer group 2, member D.

was used to analyze the phenotyping difference induced in system A and B by verifying the expression of activating and inhibitory NK cell surface-associated receptors on NK cells (Fig. 2A) and NKT cells (Fig. 2B).

The results demonstrated that, compared with the pre-culture conditions, the percentages of NK cells expressing NKG2D, an NK-activating receptor, had significantly increased in the two systems by day 14. By contrast, the percentage of NK cells expressing NKp46, another NK-activating receptor, was significantly decreased. However, the expression of the inhibitory receptors CD158a and CD158b also increased post-induction in the two systems, as presented in Fig. 2A. Of note, compared with baseline, the expression of CD94/NKG2A, an inhibitory receptor, was not changed on day 14 in either of the two systems.

The expression of these NK-activating/inhibitory receptors was also investigated in the subgroup of NKT cells. Of note, although the percentages of $\mathrm{NKG}_{2} \mathrm{D}^{+} \mathrm{NKT}$ cells increased as they did in NK cells, there was no marked change in the percentage of NKT cells expressing NKp46. In addition, the percentages of NKT cells expressing CD94/NKG2A on day 14 were opposite in the two systems [from $56 \pm 19$ to $65 \pm 16 \%$ in system $A$ and from $56 \pm 19$ to $43 \pm 16 \%$ in system $B(P<0.01$ for each; Fig. 2B)]. Furthermore, the expression of CD158a increased in the two systems, while CD158b increased in system A only (Fig. 2B).

Cytotoxicity of expanded effector cells against the K562 cell line. In the present study, K562 cells were used as target cells and an LDH assay was applied to verify the in vitro cytotoxicity on effector cells post-expansion in systems A and B. When the ratio of effector cells vs. target cells was 20:1 and 10:1, strong cytotoxicity of effector cells against target cells was detected in the two systems, however, there was no significant difference between the two systems (Fig. 3). 


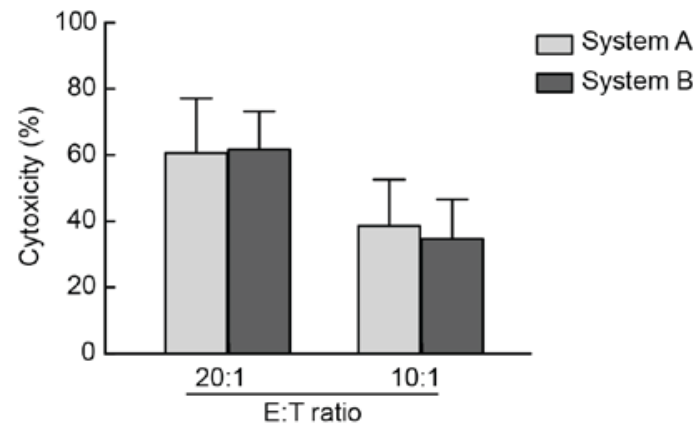

Figure 3. Cytotoxicity in vitro. Cytotoxicity of K562 in expanded cells from system A and B. a lactate dehydrogenase assay was performed on day 14 after harvesting the cells cultured at the indicated E:T ratio. K526 cells were used as the target cells. The results are expressed as mean \pm standard error of the mean from three independently performed experiments. System A/B, induction in the absence/presence of anti-CD3; E:T ratio, effector vs. target cell ratio.

Signaling pathways involved in cell proliferation and differentiation. In a previous study, immobilized TTZ was revealed to be effective in enhancing the growth of CD3-LAK cells and increasing the numbers of NK cells and $\gamma \delta^{+} \mathrm{T}$ cells (18). According to these published results, the present study established two large-scale ex vivo GMP-compliant culture systems based on immobilized TTZ and revealed that the addition of OKT3 in system B increased the expansion folds of total cells as well as $\mathrm{CD} 8^{+} \mathrm{T}$ cells compared with those in system A. However, there was no significant difference in the expansion folds of NK cells between the two systems (Fig. 1).

To explore different mechanisms involved in the proliferation of specific cell subsets, the present study analyzed the relevant protein expression and phosphorylation in the Janus kinase (JAK)/signal transducer and activator of transcription (STAT) and phosphoinositide-3 kinase (PI3K)/AKT/p70S6K1 signaling pathways in isolated $\mathrm{CD} 8^{+} \mathrm{T}$ cells or NK cells re-stimulated by IL- 2 or a combination of IL- 2 and OKT3. The results demonstrated that IL-2 re-stimulation decreased the expression of JAK3 in CD8 ${ }^{+} \mathrm{T}$ cells, and subsequent incubation with OKT3 enhanced this decrease. Furthermore, the combination of IL-2 and OKT3 decreased the expression of JAK3 in NK cells. Of note, although the expression of STAT3 phosphorylated at T705 was enhanced by IL-2, additional treatment with OKT3 reversed this increase in $\mathrm{CD} 8^{+} \mathrm{T}$ cells and NK cells. However, the expression of STAT3 did not show any change with IL-2 or, IL-2 and OKT 3 in CD8 ${ }^{+} \mathrm{T}$ cells and NK cells. Notably, although IL-2 reduced STAT5 expression, and phosphorylation at T694 in $\mathrm{CD}^{+} \mathrm{T}$ cells and NK cells, no marked change was observed following addition of anti-CD3 $\mathrm{mAb}$. These results indicated that IL-2 stimulated transcription by downregulating the expression of JAK3 in CD8 ${ }^{+} \mathrm{T}$ cells, and the phosphorylation of STAT5 at T694 in $\mathrm{CD}^{+} \mathrm{T}$ cells and NK cells, while upregulating of the phosphorylation of STAT3 at T705. Furthermore, OKT3 was involved in regulating transcription primarily through inhibiting the JAK3/STAT3 (T705) pathway (Fig. 4A).

The proliferation of $\mathrm{CD}^{+} \mathrm{T}$ cells and NK cells appeared to be associated with cyclin D3 and cyclin B1, since the expression of cyclin D3 was markedly upregulated by IL-2 re-stimulation, while the expression of cyclin B1 was downregulated following addition of OKT3. Although cyclin D3 is a target of the cyclin E/cyclin-dependent kinase (CDK)2 complex via p27Kip1 (25), the proliferation was possibly not dependent on the cyclin E/CDK2 complex, since the expression of p-CDK2 (T160) did not exhibit any change with IL- 2 in CD8 ${ }^{+} \mathrm{T}$ cells and NK cells. However, the combination of IL-2 and OKT3 decreased the phosphorylation of CDK2 at T160 in NK cells (Fig. 4B).

The regulation of protein translation was also investigated via the PI3K/AKT/p70S6K1/S6 axis. IL-2 increased the phosphorylation of PI3Kp85 at Y458 and decreased the phosphorylation of AKT at S473. Similarly, the phosphorylation of p70S6K1 at T389 and S6 at S235/S236 and S240/S244 was upregulated by IL-2 re-stimulation. Of note, additional incubation with OKT3 reversed the upregulation of the phosphorylation on PI3K p85 and S6, but reduced the phosphorylation of AKT at S473. Notably, the addition of OKT3 enhanced the phosphorylation of p70S6K1 at T389 in CD8 ${ }^{+} \mathrm{T}$ cells but not NK cells (Fig. 4C).

These results indicated that during the process of proliferation and differentiation of PBMCs, apart from regulating the cell cycle, OKT3 was typically involved in the regulation of transcription and protein translation.

Subgroup analysis. Of notable interest was the finding that the main effector cell subsets varied amongst cell cultures from different individuals even in the same culture system. Accordingly, the 22 healthy donors were divided into three groups based on the results of the cell phenotype analysis of the final product in system A: NK cell-predominant growth group (NKPG, proportion of NK cells $\geq 45 \%, n=6$ ); $\mathrm{CD} 8^{+}$cell-predominant growth group $(\mathrm{CD} 8 \mathrm{PG}$, proportion of $\mathrm{CD}^{+} / \mathrm{CD}^{+} \mathrm{T}$ cells $\geq 50 \%, \mathrm{n}=8$ ); and $\mathrm{NK}$ and $\mathrm{CD} 8^{+}$ $\mathrm{T}$ cell-balanced growth group $(\mathrm{NK}+\mathrm{CD} 8 \mathrm{BG}$, proportion of $\mathrm{NK}$ cells $<45 \%$ and the proportion of $\mathrm{CD}^{+} / \mathrm{CD}^{+} \mathrm{T}$ cells $<50 \%, \mathrm{n}=8)$. The subsets of effector cells $\left(\mathrm{CD}^{+}\right.$, $\mathrm{CD}^{+} / \mathrm{CD}^{+}, \mathrm{CD}^{+} / \mathrm{CD}^{+}, \mathrm{CD}^{-} / \mathrm{CD} 6^{+}$and $\left.\mathrm{CD}^{+} / \mathrm{CD} 56^{+}\right)$ in different subgroups in system $\mathrm{A}$ and system $\mathrm{B}$ were then compared. The results demonstrated that the percentage of total effector T cells $\left(\mathrm{CD}^{+}\right)$in the $\mathrm{CD} 8 \mathrm{PG}$ group was significantly higher than that in the NKPG group in system A as well as in system B (Fig. 5A). Although in system B, no significant difference was present between the CD8PG and $\mathrm{CD} 8+\mathrm{NKBG}$ groups, the percentage of $\mathrm{CD}^{+}$cells in the $\mathrm{CD} 8+\mathrm{NKBG}$ group was still significantly greater than that in NKPG group in system A. The percentage of $\mathrm{CD}^{+} / \mathrm{CD}^{+}$ cells did not exhibit any difference between different subgroups in system B, although in system A, it was higher in the CD8+NKBG group compared with that in the NKPG and CD8PG groups (Fig. 5B). Differences in the percentages of $\mathrm{CD}^{+} / \mathrm{CD}^{+}$and $\mathrm{CD} 3 / \mathrm{CD}^{-} 6^{+}$cells were consistent between the two systems, since in the $\mathrm{CD} 8 \mathrm{PG}$ group, $\mathrm{CD}^{+} / \mathrm{CD}^{+}$cells were significantly enhanced compared with those in the other two groups (Fig. 5C), while CD3-/CD56 ${ }^{+}$cells predominated in the NKPG group (Fig. 5D). Furthermore, no difference was observed in the percentage of NKT $\left(\mathrm{CD}^{+} / \mathrm{CD}^{2} 6^{+}\right)$cells between different subgroups in either system (Fig. 5E). These results assured that the major subset of effector cells expanded from different subgroups was consistent between the two culture systems.

Additional comparison of the expression of activating $\left(\mathrm{NKG}_{2} \mathrm{D}^{+}\right.$and $\left.\mathrm{NKp} 46^{+}\right)$and inhibitory $\left(\mathrm{CD} 94^{+}, \mathrm{CD} 158 \mathrm{a}^{+}\right.$and $\left.\mathrm{CD} 158 \mathrm{~b}^{+}\right) \mathrm{NK}$ cell surface-associated receptors on the NK 
A

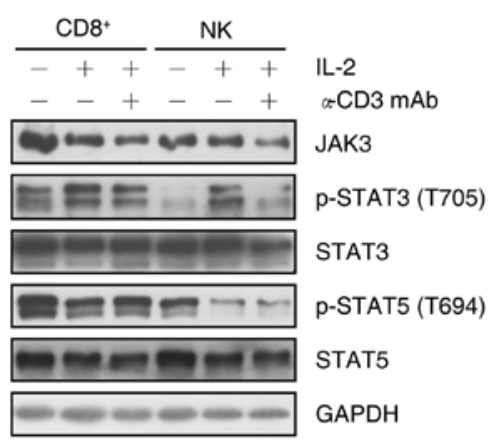

B

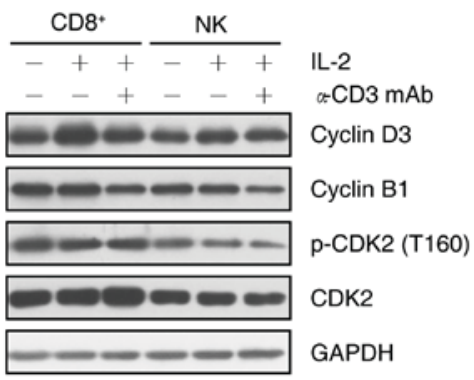

C

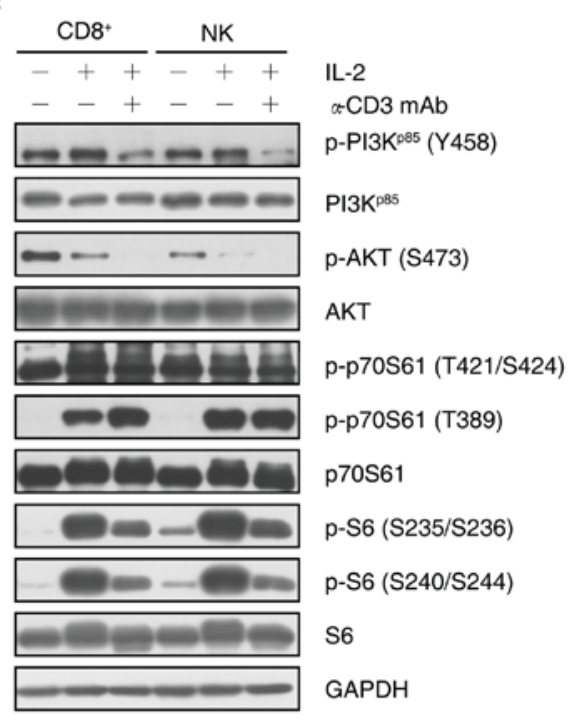

Figure 4. Effects of IL-2 and anti-CD3 antibody on JAK/STAT and PI3K/AKT/p70S6K1 signaling pathways and cell cycle regulation in CD8 ${ }^{+} \mathrm{T}$ and NK cells. Cultures enriched in $\mathrm{CD}^{+} \mathrm{T}$ and NK cells were harvested at day 9 and stimulated with either IL-2 only or anti-CD3/IL-2 for $24 \mathrm{~h}$ prior to protein extraction. Western blot analysis was performed to identify the variations in the expression of relevant proteins and their phosphorylation products. (A) JAK/STAT, (B) cell cycle regulatory proteins and (C) PI3K/AKT/p70S6K1/S6 axis in CD8 ${ }^{+} \mathrm{T}$ and NK cells. PI3K, phosphoinositide-3 kinase; IL, interleukin; JAK, Janus kinase; p-STAT, phosphorylated signal transducer and activator of transcription; CDK, cyclin D kinase; mAb, monoclonal antibody; IL, interleukin; NK, natural killer.

and NKT cells derived from different individuals indicated that no significant difference was present among the three groups following the expansion in systems A and B (data not shown). Similarly, no substantial difference in cytotoxicity of the expanded effector cells was identified among the three subgroups in either system (Fig. 6).

\section{Discussion}

Large quantities of activated effector cells are required for successful adoptive immunotherapy. The present study aimed to optimize the ex vivo expansion systems for clinical-grade effector cells. Two large-scale ex vivo effector cell culture systems were established, in which PBMCs derived from healthy donors were stimulated with HER-2 antibody or co-stimulated with HER-2 antibody and anti-CD3 antibody. It was revealed that HER-2 antibody stimulus promoted the preferential proliferation of NK cells. It is known that NK cells recognize tumor cells through Fc $\gamma$ receptors combining with Fc $\gamma$ of TTZ on tumor cell surfaces, and then kill the tumor cells via ADCC effects (26-30). A TTZ coating on the surface of culture flasks may recruit NK cells from PBMCs via Fc $\gamma$ to activate NK cells and promote NK cell proliferation. This effect may be similar to the role of feeder cells. OKT3 has been commonly used in PBMCs to induce the proliferation of NK cells, suggesting that OKT3 does not only induce $\mathrm{T}$-cell proliferation but also promotes $\mathrm{T}$-cell generating cytokines that support NK cell proliferation (31). However, in the present study, OKT3 co-stimulation evidently enhanced the expansion of the total cells, but primarily induced PBMCs to differentiate into $\mathrm{CD}^{+} \mathrm{T}$ cells, as the proportion of $\mathrm{CD}^{+} \mathrm{CD}^{+}$and $\mathrm{CD}^{+} \mathrm{CD}^{+}{ }^{+} \mathrm{T}$ cells was higher in the HER-2 and anti-CD3 antibody co-stimulation system.

The signaling pathways involved in the proliferation and differentiation of PBMCs induced by OKT3 co-stimulation were investigated. A previous study demonstrated that after $168 \mathrm{~h}$ of induced activation of PMBCs via anti-CD3 monoclonal antibody, they responded to re-stimulation by anti-CD3 monoclonal antibody. IL-2 and IL- $2 \mathrm{R} \beta \gamma$ are known combine to activate JAK, thereby activating the three downstream signaling pathways STAT, PI3K-AKT and MAPK (32). The present study indicated that IL-2 stimulation promoted the proliferation of $\mathrm{CD}^{+} \mathrm{T}$ cells and NK cells via the PI3K/p70S6K1 signaling pathway, while the stimulation effect of anti-CD3 monoclonal antibody on cell proliferation was relatively weak. Therefore, anti-CD3 monoclonal antibody may primarily serve as an inducer of cell differentiation. Stimulation by addition of OKT3 may enhance total cell proliferation through stimulating the secretion of growth-associated cytokines.

The cytotoxicity of NK cells and NKT cells is determined by the balance of signals from activating and inhibitory receptors on the effector cell surface. NKG2D was first reported to be an activated receptor of NK cells. It is not only expressed on the NK cell surface, but also on NKT-cells and $\gamma \delta^{+} \mathrm{T}$ cell subsets (33-36). In vitro studies have demonstrated that binding of NKG2D and its ligands provides signals for NK cell activation and co-stimulatory signals for T-cells $(35,37,38)$. Through the binding of MHC class I chain-related molecule (MIC)A, MICB or human cytomegalovirus glycoprotein UL16 binding 

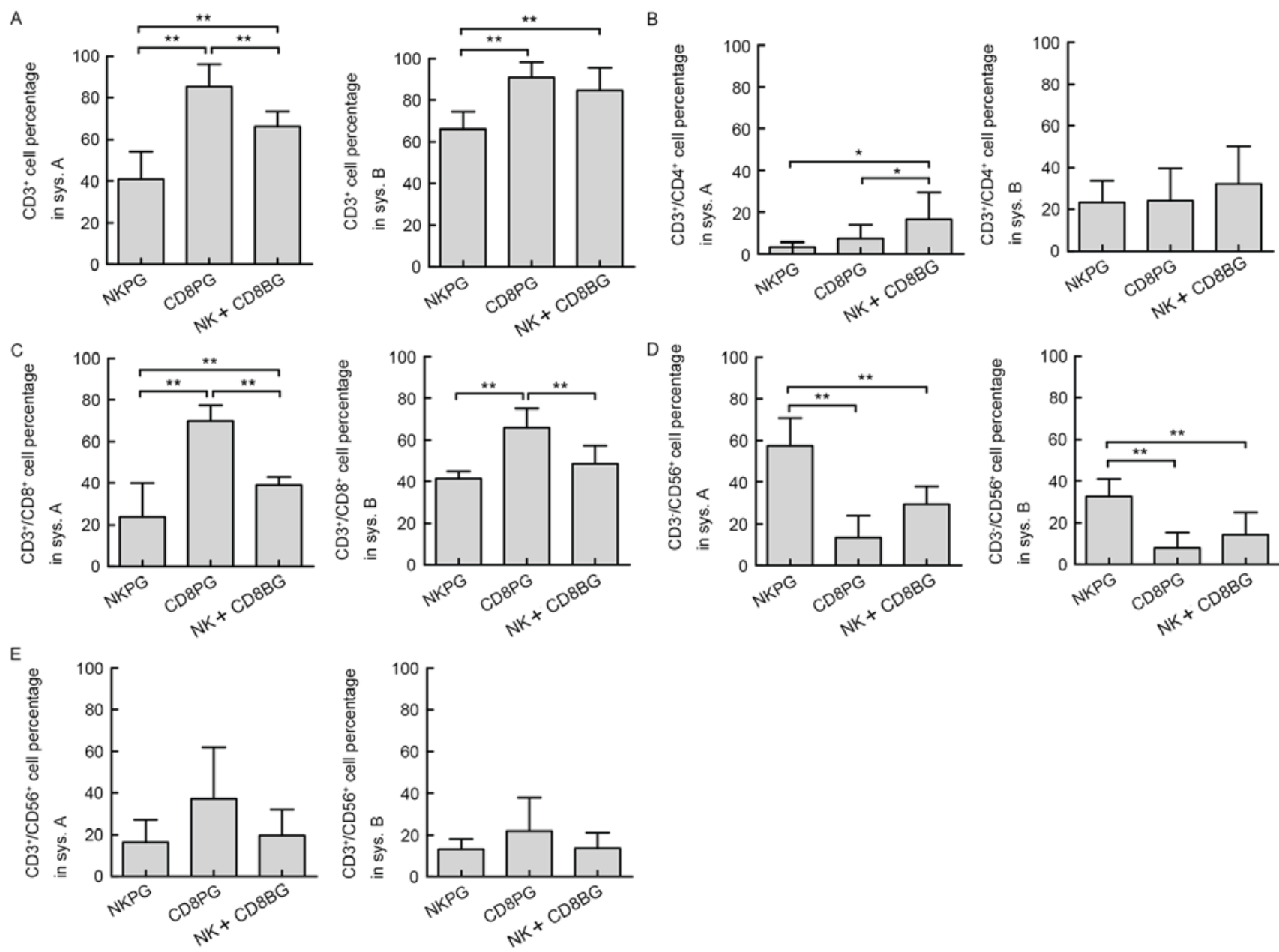

Figure 5. Subgroup analysis of expanded cell subsets. The 22 healthy donors were divided into three groups based on the results of cell phenotype analysis of the final product in system A: NKPG, proportion of NK cells $\geq 45 \%$; CD8PG, proportion of $\mathrm{CD}^{+} / \mathrm{CD} 8+\mathrm{T}$ cells $\geq 50 \%$; and NK $+\mathrm{CD} 8 \mathrm{BG}$, proportion of $\mathrm{NK}$ cells $<45 \%$ and proportion of $\mathrm{CD}^{+} / \mathrm{CD}^{+} \mathrm{T}$ cells $<50 \%$. Subsets of effector cells, including (A) $\mathrm{CD}^{+}$, (B) $\mathrm{CD}^{+} / \mathrm{CD}^{+}$, (C) $\mathrm{CD}^{+} / \mathrm{CD}^{+}$, (D) $\mathrm{CD}^{-} / \mathrm{CD}^{2} 6^{+}$ and $(\mathrm{E}) \mathrm{CD}^{+} / \mathrm{CD} 6^{+}$expanded in peripheral blood mononuclear cells from different subgroups in systems $\mathrm{A}$ and $\mathrm{B}$ were evaluated. Values are expressed as the mean \pm standard error of the mean. $\mathrm{P}<0.05$ and ${ }^{* *} \mathrm{P}<0.01$. NK, natural killer; System A/B, induction in the absence/presence of anti-CD3.

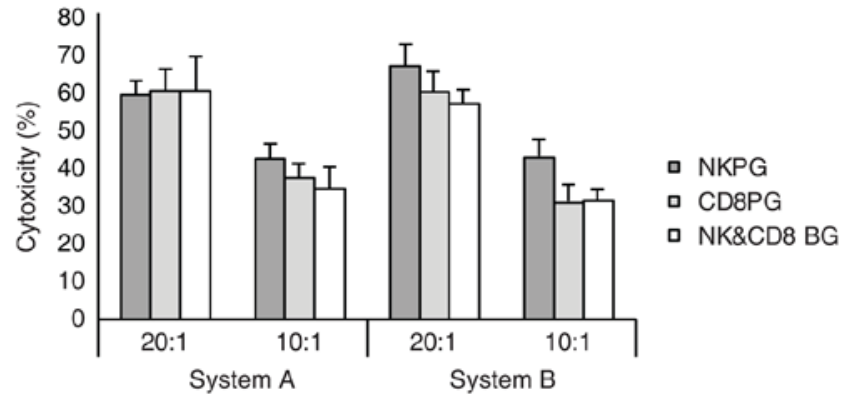

Figure 6. Subgroup analysis of cytotoxicity on expanded cells. The cytotoxicity of K562 in expanded cells from the NKPG, CD8PG and NK+CD8BG groups in systems A and B was assessed. A lactate dehydrogenase assay was performed on day 14 after harvesting the cells at the indicated ratios of effector cells vs. target cells. K526 cells were used as the target cells. Results are expressed as mean \pm standard error of the mean from three independently performed experiments. Groups: NKPG, proportion of NK cells $\geq 45 \%$; CD8PG, proportion of $\mathrm{CD}^{+} / \mathrm{CD} 8^{+} \mathrm{T}$ cells $\geq 50 \%$; and $\mathrm{NK}+\mathrm{CD} 8 \mathrm{BG}$, proportion of $\mathrm{NK}$ cells $<45 \%$ and proportion of $\mathrm{CD}^{+} / \mathrm{CD}^{+} \mathrm{T}$ cells $<50 \%$. NK, natural killer; system $\mathrm{A} / \mathrm{B}$, induction in the absence/presence of anti-CD3.

proteins to NKG2D, the receptor recognizes tumor cells and secretes perforin and granzymes to kill tumor cells (39-44).
The results of the present study indicated that although the effector cell phenotypes of PBMCs derived from different individuals varied in systems $\mathrm{A}$ and $\mathrm{B}$, the expression of a variety of activating and inhibitory receptors of harvested NK and NKT cells were not different based on which system was used. Despite the different phenotypic characteristics, effector cells generated in the two culture systems had similarly strong cytotoxicity against tumor cells, which may be interpreted in the light of the results of in vivo and in vitro studies reporting that $\mathrm{NK}$ cells continuously promoted the response of CD8 ${ }^{+}$ $\mathrm{T}$ cells $(45,46)$. A clinical study also confirmed that a high proportion of $\mathrm{CD}^{+} / \mathrm{CD}^{+} \mathrm{T}$ cell subsets in CIK cell transfusion was associated with improved the overall survival rate in patients with hepatocellular carcinoma, lung cancer and colorectal cancer (47).

The present study revealed that PBMCs derived from different individuals exhibited three distinct proliferation and differentiation patterns under the same culture conditions. This phenomenon was reported in a previous study demonstrating that PBMCs derived from healthy donors had a high proportion of NK cells and a relatively low proportion of $\mathrm{CD}^{+} \mathrm{T}$ cell following the in vitro expansion; however, no other subgroup 
analysis was performed (31). It was reported that the number of harvested NK cells in the culture was associated with the number of NK cells in the peripheral blood sample originally drawn (48). By contrast, the proportion of NK cell subsets in the NKPG group prior to in vitro culture was not significantly different from that in the other two groups of the present study. Thus, the significant NK cell proliferation in the NKPG group was unlikely to have been caused by the high proportion of NK cell subsets in PBMCs prior to the in vitro culture, but may have been associated with the genetic background of the population, such as the expression of NK cell surface Fc $\gamma$ receptors.

In conclusion, the two in vitro GMP-compliant culture systems used in the present study effectively induced the activation, proliferation and differentiation of immune effector cells. The method of TTZ immobilization was easy and safe to operate without the requirement of feeder cells to induce NK cell expansion from unselected PBMCs. Addition of OKT3 promoted the total cell proliferation and primarily induced the PBMC to differentiate into $\mathrm{CD}^{+} \mathrm{T}$ cells. Thus, the present study provided GMP-compliant methods for the generation of large-scale clinical-grade effector cells for adoptive immunotherapy. However, the composition of produced effector cells varied largely among the donors, which must be taken into consideration when a high purity of specific cell subset is required for treatment. The mechanisms underlying variations among donors require additional investigation.

\section{References}

1. Ruella M and Kalos M: Adoptive immunotherapy for cancer. Immunol Rev 257: 14-38, 2014.

2. Shimasaki N, Coustan-Smith E, Kamiya T and Campana D: Expanded and armed natural killer cells for cancer treatment. Cytotherapy 18: 1422-1434, 2016.

3. Introna M: CIK as therapeutic agents against tumors J Autoimmun Jul 2, 2017 (Epub ahead of print).

4. Bollino D and Webb TJ: Chimeric antigen receptor-engineered natural killer and natural killer T cells for cancer immunotherapy. Transl Res 187: 32-43, 2017.

5. Ping Y, Liu C and Zhang Y: T-cell receptor-engineered T cells for cancer treatment: Current status and future directions. Protein Cell Jan 20, 2017 (Epub ahead of print).

6. Zhang BL, Qin DY, Mo ZM, Li Y, Wei W, Wang YS, Wang W and Wei YQ: Hurdles of CAR-T cell-based cancer immunotherapy directed against solid tumors. Sci China Life Sci 59: 340-348, 2016.

7. Shi FD, Ljunggren HG, La Cava A and Van Kaer L: Organ-specific features of natural killer cells. Nat Rev Immunol 11: 658-671, 2011.

8. Konjević G, Mirjacić Martinović K, Vuletić A, Jurisić V and Spuzić I: Distribution of several activating and inhibitory receptors on CD3-CD16+ NK cells and their correlation with NK cell function in healthy individuals. J Membr Biol 230: 113-123, 2009.

9. Caligiuri MA: Human natural killer cells. Blood 112: 461-469, 2008.

10. Jiang $\mathrm{J}, \mathrm{Wu} \mathrm{C}$ and $\mathrm{Lu} \mathrm{B}$ : Cytokine-induced killer cells promote antitumor immunity. J Transl Med 11: 83, 2013.

11. Schmidt-Wolf IG, Lefterova P, Mehta BA, Fernandez LP, Huhn D, Blume KG, Weissman IL and Negrin RS: Phenotypic characterization and identification of effector cells involved in tumor cell recognition of cytokine-induced killer cells. Exp Hematol 21: 1673-1679, 1993.

12. Lu PH and Negrin RS: A novel population of expanded human CD3+CD56+ cells derived from T cells with potent in vivo antitumor activity in mice with severe combined immunodeficiency. J Immunol 153: 1687-1696, 1994.

13. Maniar A, Zhang X, Lin W, Gastman BR, Pauza CD, Strome SE and Chapoval AI: Human gammadelta T lymphocytes induce robust NK cell-mediated antitumor cytotoxicity through CD137 engagement. Blood 116: 1726-1733, 2010.
14. Pittari G, Filippini P, Gentilcore G, Grivel JC and Rutella S: Revving up natural killer cells and cytokine-induced killer cells against hematological Malignancies. Front Immunol 6: 230, 2015.

15. Berg M, Lundqvist A, McCoy P Jr., Samsel L, Fan Y, Tawab A and Childs R: Clinical-grade ex vivo-expanded human natural killer cells up-regulate activating receptors and death receptor ligands and have enhanced cytolytic activity against tumor cells. Cytotherapy 11: 341-355, 2009.

16. Fujisaki H, Kakuda H, Shimasaki N, Imai C, Ma J, Lockey T, Eldridge P, Leung WH and Campana D: Expansion of highly cytotoxic human natural killer cells for cancer cell therapy. Cancer Res 69: 4010-4017, 2009.

17. Siegler U, Meyer-Monard S, Jörger S, Stern M, Tichelli A, Gratwohl A, Wodnar-Filipowicz A and Kalberer CP: Good manufacturing practice-compliant cell sorting and large-scale expansion of single KIR-positive alloreactive human natural killer cells for multiple infusions to leukemia patients. Cytotherapy 12: 750-763, 2010.

18. Gong W, Xiao W, Hu M, Weng X, Qian L, Pan X and Ji M: Ex vivo expansion of natural killer cells with high cytotoxicity by K562 cells modified to co-express major histocompatibility complex class I chain-related protein A, 4-1BB ligand and interleukin-15. Tissue Antigens 76: 467-475, 2010.

19. Childs RW and Berg M: Bringing natural killer cells to the clinic: Ex vivo manipulation. Hematology Am Soc Hematol Educ Program 2013: 234-246, 2013.

20. Cobleigh MA, Vogel CL, Tripathy D, Robert NJ, Scholl S, Fehrenbacher L, Wolter JM, PatonV, Shak S, Lieberman G and Slamon DJ: Multinational study of the efficacy and safety of humanized anti-HER 2 monoclonal antibody in women who have HER2-overexpressing metastatic breast cancer that has progressed after chemotherapy for metastatic disease. J Clin Oncol 17: 2639-2648, 1999.

21. Albanell J, Bellmunt J, Molina R, García M, Caragol I, Bermejo B, Ribas A, Carulla J, Gallego OS, Español T and Solé Calvo LA: Node-negative breast cancers with p53(-)/HER2-neu(-) status may identify women with very good prognosis. Anticancer Res 16: 1027-1032, 1996.

22. Steplewski Z, Lubeck MD and Koprowski H: Human macrophages armed with murine immunoglobulin G2a antibodies to tumors destroy human cancer cells. Science 221: 865-867, 1983.

23. Shields RL, Namenuk AK, Hong K, Meng YG, Rae J, Briggs J, Xie D, Lai J, Stadlen A, Li B, et al: High resolution mapping of the binding site on human IgG1 for Fc gamma RI, Fc gamma RII, Fc gamma RIII and FcRn and design of IgG1 variants with improved binding to the Fc gamma R. J Biol Chem 276: 6591-6604, 2001

24. Nakagawa S, Matsuoka Y, Ichihara H, Yoshida H, Yoshida K and Ueoka R: New cancer immunotherapy using autologous lymphocytes activated with trastuzumab. Biol Pharm Bull 35: 1213-1215, 2012.

25. Barnouin K, Fredersdorf S, Eddaoudi A, Mittnacht S, Pan LX, Du MQ and Lu X: Antiproliferative function of p27kip1 is frequently inhibited in highly malignant Burkitt's lymphoma cells. Oncogene 18: 6388-6397, 1999.

26. Whenham N, D'Hondt V and Piccart MJ: HER2-positive breast cancer: From trastuzumab to innovatory anti-HER2 strategies. Clin Breast Cancer 8: 38-49, 2008.

27. Baselga J, Gianni L, Geyer C, Perez EA, Riva A and Jackisch C: Future options with trastuzumab for primary systemic and adjuvant therapy. Semin Oncol 31 (5 Suppl 10): S51-S57, 2004.

28. Hudis CA: Trastuzumab-mechanism of action and use in clinical practice. N Engl J Med 357: 39-51, 2007.

29. Nimmerjahn F and Ravetch JV: Antibodies, Fc receptors and cancer. Curr Opin Immunol 19: 239-245, 2007.

30. Beano A, Signorino E, Evangelista A, Brusa D, Mistrangelo M, Polimeni MA, Spadi R, Donadio M, Ciuffreda L and Matera L: Correlation between NK function and response to trastuzumab in metastatic breast cancer patients. J Transl Med 6: 25, 2008.

31. Huijskens MJ, Walczak M, Sarkar S, Atrafi F, Senden-Gijsbers BL, Tilanus MG, Bos GM, Wieten L and Germeraad WT: Ascorbic acid promotes proliferation of natural killer cell populations in culture systems applicable for natural killer cell therapy. Cytotherapy 17: 613-620, 2015.

32. Malek TR: The biology of interleukin-2. Annu Rev Immunol 26: 453-479, 2008.

33. Groh V, Rhinehart R, Secrist H, Bauer S, Grabstein KH and Spies T: Broad tumor-associated expression and recognition by tumor-derived gamma delta T cells of MICA and MICB. Proc Natl Acad Sci USA 96: 6879-6884, 1999. 
34. Vivier E, Tomasello E and Paul P: Lymphocyte activation via NKG2D: Towards a new paradigm in immune recognition?. Curr Opin Immunol 14: 306-311, 2002.

35. Groh V, Rhinehart R, Randolph-Habecker J, Topp MS Riddell SR and Spies T: Costimulation of CD8alphabeta T cells by NKG2D via engagement by MIC induced on virus-infected cells. Nat Immunol 2: 255-260, 2001.

36. Wang H, Yang D, Xu W, Wang Y, Ruan Z, Zhao T, Han J and Wu Y: Tumor-derived soluble MICs impair CD3(+)CD56(+) NKT-like cell cytotoxicity in cancer patients. Immunol Lett 120: 65-71, 2008.

37. Bauer S, Groh V, Wu J, Steinle A, Phillips JH, Lanier LL and Spies T: Activation of NK cells and T cells by NKG2D, a receptor for stress-inducible MICA. Science 285: 727-729, 1999.

38. Diefenbach A, Jamieson AM, Liu SD, Shastri N and Raulet DH: Ligands for the murine NKG2D receptor: Expression by tumor cells and activation of NK cells and macrophages. Nat Immunol 1: 119-126, 2000.

39. Meyer A, Carapito R, Ott L, Radosavljevic M, Georgel P, Adams EJ, Parham P, Bontrop RE, Blancher A and Bahram S: High diversity of MIC genes in non-human primates. Immunogenetics 66: 581-587, 2014.

40. Pende D, Rivera P, Marcenaro S, Chang CC, Biassoni R, Conte R, Kubin M, Cosman D, Ferrone S, Moretta L and Moretta A: Major histocompatibility complex class I-related chain A and UL16-binding protein expression on tumor cell lines of different histotypes: Analysis of tumor susceptibility to NKG2D-dependent natural killer cell cytotoxicity. Cancer Res 62: 6178-6186, 2002.

41. Friese MA, Platten M, Lutz SZ, Naumann U, Aulwurm S, Bischof F, Bühring HJ, Dichgans J, Rammensee HG, Steinle A and Weller M: MICA/NKG2D-mediated immunogene therapy of experimental gliomas. Cancer Res 63: 8996-9006, 2003.
42. Salih HR, Antropius H, Gieseke F, Lutz SZ, Kanz L, Rammensee HG and Steinle A: Functional expression and release of ligands for the activating immunoreceptor NKG2D in leukemia. Blood 102: 1389-1396, 2003.

43. Watson NF, Spendlove I, Madjd Z, McGilvray R, Green AR, Ellis IO, Scholefield JH and Durrant LG: Expression of the stress-related MHC class I chain-related protein MICA is an indicator of good prognosis in colorectal cancer patients. Int J Cancer 118: 1445-1452, 2006.

44. Vetter CS, Groh V, thor Straten P, Spies T, Brocker EB and Becker JC: Expression of stress-induced MHC class I related chain molecules on human melanoma. J Invest Dermatol 118: 600-605, 2002

45. Assarsson E, Kambayashi T, Schatzle JD, Cramer SO, von Bonin A, Jensen PE, Ljunggren HG and Chambers BJ: NK cells stimulate proliferation of $\mathrm{T}$ and NK cells through $2 \mathrm{~B} 4 / \mathrm{CD} 48$ interactions. J Immunol 173: 174-180, 2004.

46. Martin-Fontecha A, Thomsen LL, Brett S, Gerard C, Lipp M, Lanzavecchia A and Sallusto F: Induced recruitment of NK cells to lymph nodes provides IFN-gamma for $\mathrm{T}(\mathrm{H}) 1$ priming. Nat Immunol 5: 1260-1265, 2004.

47. Pan K, Wang QJ, Liu Q, Zheng HX, Li YQ, Weng DS, Li JJ, Huang LX, He J, Chen SP, et al: The phenotype of ex vivo generated cytokine-induced killer cells is associated with overall survival in patients with cancer. Tumour Biol 35: 701-707, 2014.

48. Meyer-Monard S, Passweg J, Siegler U, Kalberer C, Koehl U, Rovó A, Halter J, Stern M, Heim D, Alois Gratwohl JR and Tichelli A: Clinical-grade purification of natural killer cells in haploidentical hematopoietic stem cell transplantation. Transfusion 49: 362-371, 2009. 